\title{
An Unexpected Complication: Acute Recanalization of Carotico-jugular Arteriovenous Fistulas Previously Treated by Endovascular Therapy
}

\section{Beklenmedik Komplikasyon: Endovasküler Yöntem ile Tedavi Edilen Karotiko-juguler Arteriovenöz Fistülün Akut Rekanalizasyonu}

\author{
Funda Yıldırım ${ }^{1 *}$, Dilşad Amanvermez Şenarslan ${ }^{1}$, Abdülkerim Damar² \\ ${ }^{1}$ Department of Cardiovascular Surgery, MD, Manisa Celal Bayar University, Manisa, Turkey. \\ ${ }^{2}$ Cardiovascular Surgery, İskenderun State Hospital, Hatay, Turkey. \\ e-mail: fundanizamoglu@yahoo.com,damanvermez@yahoo.com, kerimdamarctf@gmail.com \\ ORCID: 0000-0002-1577-0281 \\ ORCID: 0000-0002-3316-6707 \\ ORCID: 0000-0002-4629-5321 \\ *Sorumlu yazar/ Corresponding Author: Funda Yıldırım \\ Gönderim Tarihi / Received: 02.11.2021 \\ Kabul Tarihi / Accepted: 08.11.2021 \\ DOI: $10.34087 /$ cbusbed.1017997
}

\section{Öz}

Boyun travmatik arteriyovenöz fistülleri hastanın klinik tablosuna ve acil durumun derecesine göre endovasküler yöntemle veya açı cerrahi ile tedavi edilir. Bu olgu sunumu, biri sağ ana karotid arter ile sağ internal juguler ven arasında, diğeri ise fasiyal arter ile sağ juguler ven arasında olmak üzere, daha önce penetran boyun travmasının neden olduğu, iki geç başlangıçlı boyun fistülü ile ilgilidir. Başlangıçta gelişen arteriovenöz fistüller, çoklu vasküler tıkaçlar ve kaplı stent kullanılarak endovasküler yöntem ile tedavi edildi. Dört yıl sonra eski fistül yolunun akut rekanalizasyonu nedeniyle senkop ile acil servise başvuran hastaya yaptığımız cerrahi yöntemi bu vaka sunumunda anlatt1k.

Anahtar kelimeler: Arteriovenöz fistül, Endovasküler tedavi, Juguler ven, Karotid arter, Vasküler tıkaç

\section{Abstract}

Traumatic arteriovenous fistulas of the neck are treated by the endovascular method or by open surgery according to the clinical presentation of the patient and the degree of emergency. This case report concerns two delayed onset neck fistulas, one between the right common carotid artery and the right internal jugular vein, and the other between the facial artery and the right jugular vein, caused by a previous penetrating neck trauma. Initially, the AV fistula was treated by endovascular intervention using multiple vascular plugs and a covered stent. In this case report, we describe the surgical method we performed on a patient who applied to the emergency department with syncope due to acute recanalization of the old fistula tract four years later.

Key words: Arteriovenous fistula, Carotid artery, Endovascular therapy, Jugular veins, Vascular plug

\section{Giriş}

Traumatic arterio-venous fistulas are observed in places where the artery and vein coexist together, mostly due to a penetrating injury like a stab wound, gun-shot, fracture, iatrogenic reasons or after a surgery. These fistulas can be treated either by open surgery or by endovascular intervention. We report this remarkable case because of its extraordinary clinical presentation.

\section{Case report}

A 58-year-old man presented to the emergency department with syncope. He was intubated, unconscious and had a swollen neck without any sign of trauma. He was referred to our vascular clinic because of a pulsatile mass over the right carotid-jugular area. Physical examination showed no sign of new trauma or a new entrance on the skin. A continuous murmur was 
heard over the mass, which was located on the right side of the neck. Computed tomography angiography demonstrated a contrast flow between the right common carotid artery (CCA) and the right internal jugular vein (IJV). There was an aneurysm $8 \mathrm{~cm}$ in diameter in the right IJV. An opacified image which was thought to be related to a previous stent was observed inside the right CCA. The right internal carotid artery (ICA) and external carotid artery (ECA) were occluded by metallic prosthetic material as shown in Figure 1.

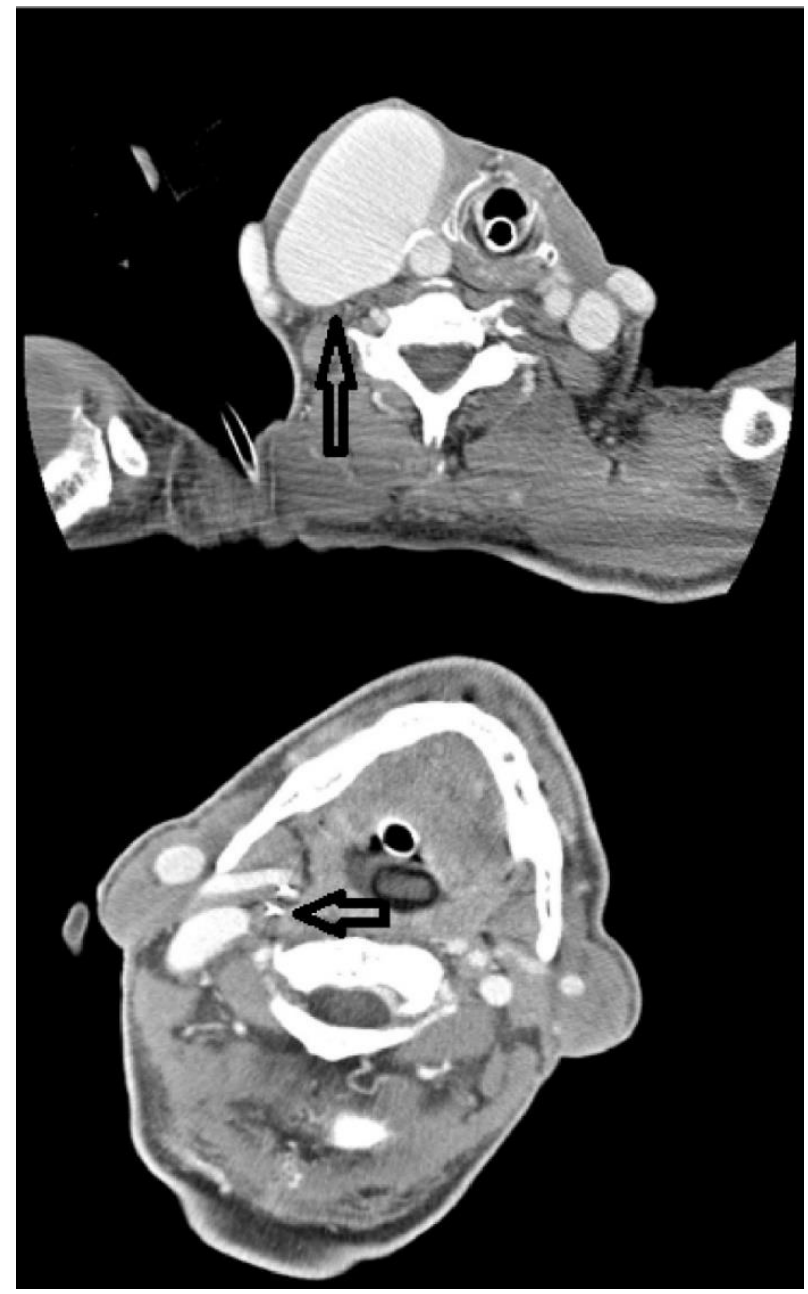

Figure 1: CTA view of the patient at two levels: the large arrow shows the IJV aneurysm, and the small arrow shows the metallic prosthetic material reflection.

We found out from the past hospital records that the patient had been admitted to our clinic five years ago because of an arteriovenous fistula between the right carotid artery and IJV that was caused by a former penetrating neck injury involving stabbing. He had undergone an endovascular procedure at another vascular clinic for AV-fistula, a covered stent had been placed in the right CCA to close the fistula tract, and four vascular plugs had been implanted. The patient had previously been asymptomatic. Considering the circumstances, we thought that the material used for occlusion of the fistula tract had been displaced after a blunt trauma. The migration of the plug had led to an acute recanalization of the AV-fistula tract and a swelling on the neck had occurred. The patient was found unconscious and taken to the hospital by an emergency transport team.

After the clinical and radiological evaluation of the patient, we decided to perform conventional surgery to expose the arteriovenous fistula in the neck. The pulsatile mass was explored by standard incision parallel to the sternocleidomastoid muscle. Two fistula tracts between the right CCA and IJV were observed and then ligated. The thrill on the neck was disappeared. However, the distal ECA and ICA pulses were absent. Therefore, the arteriotomy was extended to these arteries. The stent inside the CCA was seen, and the lumen of the ECA and ICA were occluded by endoluminal Amplatzer vascular plugs. The materials causing occlusion and the stented segment of the CCA were removed. The defective $6-8 \mathrm{~cm}$ segment of the carotid artery was repaired with a $6 \mathrm{~mm}$ ringed ePTFE graft interposition (Figure 2), and the right ECA was ligated. The aneurysmatic IJV was plicated over itself to minimize its diameter.

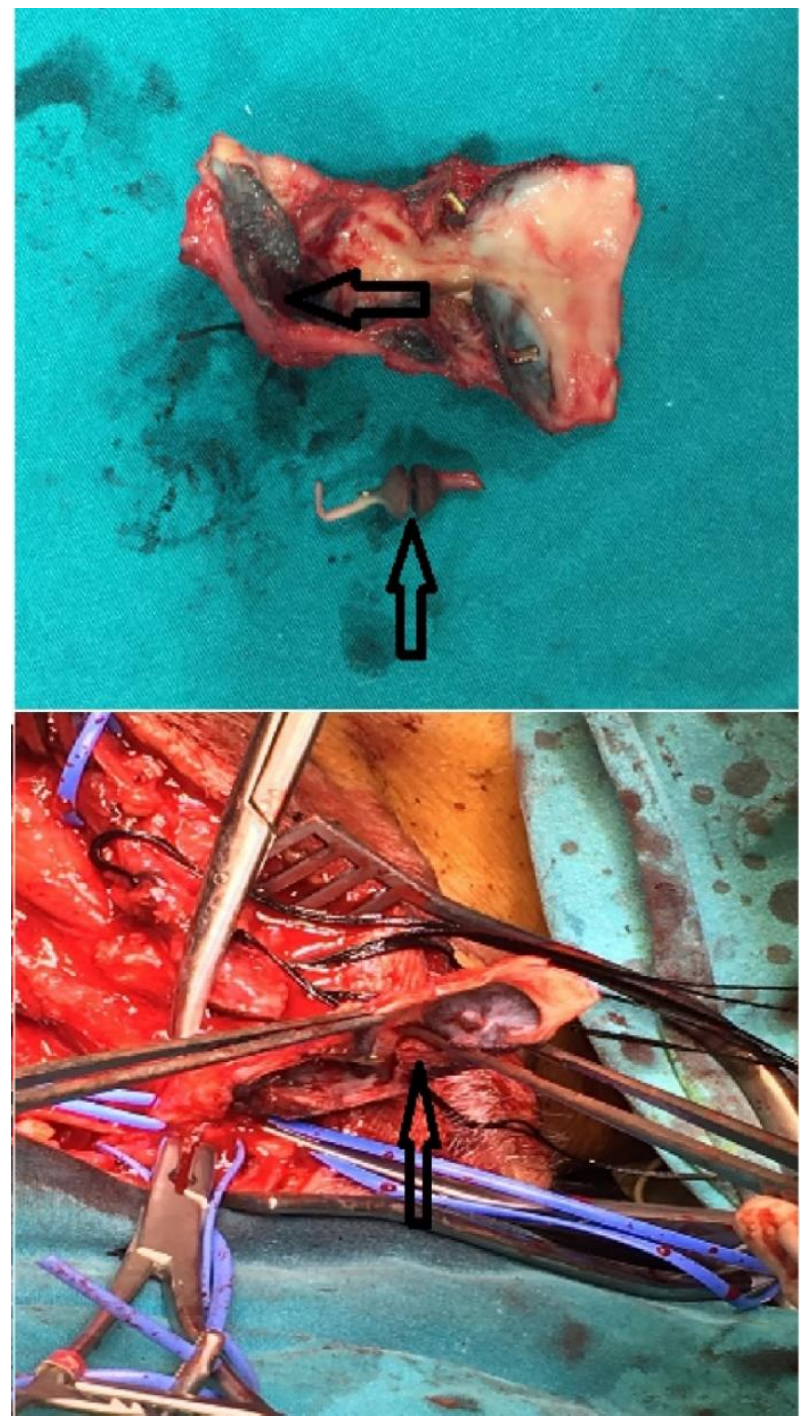

Figure 2: The removed coil material that occluded the right internal carotid artery, and the operation view of the arteriovenous fistula 
During the operation, we observed considerable bleeding from the distal end of the right ICA. After the operation, the patient regained consciousness, and he was discharged from the hospital on the fourth postoperative day without any neurological sequellae.

\section{Discussion}

Arteriovenous fistulas of the neck are mostly secondary to trauma, but they can also be congenital, spontaneous or iatrogenic.[1] Congenital fistulas are extremely rare and there are few case reports in the literature.[2,3] Nowadays, iatrogenic AV-fistulas are observed more frequently in the neck region because of the increased number of catheterizations needed for central venous access or temporary hemodialysis and cardiac pacing.[4] Vascular injuries to the neck arteries necessitate a rapid correction. Otherwise, serious complications like hemorrhage, pseudoaneurysm, arterial dissection, partial transection, intimal flap, occlusion, neurological injury, airway obstruction or AV fistula may occur. [5] There are a few case reports in the literature regarding carotid-jugular AV fistulas. Treatment choice depends on the patient's clinical presentation and the etiological factor. The traditional treatment is surgery, but endovascular occlusion of the fistula tract enables a less invasive option. [6]

This case is a very rare and interesting one, reported as a delayed complication of endovascular closure of the high flow fistula in the neck with a vascular plug. The ICA flow was suddenly blocked by embolization of the vascular plug, and the patient lost consciousness. In this case, delayed embolization of the vascular plug occurred approximately four years after a successful deployment. As seen in Figure 2, the embolized device was an Amplatzer vascular plug type IV. The endovascular stent-graft in the right CCA was also removed. We could not determine the exact cause of the plug migration. Because the patient was found unconscious, he could not describe anything that triggered the embolization, such as blunt trauma or sudden motion.

Vascular injuries of the neck and their complications in the long term like fistula formation are managed by ligation of the injured vessels, surgical repair of the vessels, or endovascular intervention.[7] In our case, the fistula was treated by the endovascular method and the patient remained well for four years. Percutaneous embolization of vascular fistulas can be performed with good results.[8] The choice of device can vary according to fistula tract size. Small diameter tracts can be occluded by coils but for larger ones greater than 4 $\mathrm{mm}$ in diameter, vascular plugs are preferred for the occlusion of the fistula tract. These plugs have a lower risk of embolization and increase the success of the procedure.[9]

In a review article, Dubose et al. reported results regarding 113 cases of traumatic ICA injuries treated by endovascular therapy.[5] They stated that endovascular therapy is most commonly used after blunt trauma, and that initial endovascular stent placement was successful in $76.1 \%$ of patients. They revealed a follow-up patency of $79.6 \%$. The follow-up time ranged between two weeks and two years in these subjects. Also, they reported that the rate of new neurological deficits was $3.5 \%$ after stent placement. Covered stent grafts are the first choice for closing an AV fistula defect. Published experience remains limited, and further data about the exact role of this treatment modality may be defined better with larger prospective randomized trials.

\section{Conclusion}

In conclusion, arteriovenous fistulas of the neck are rarely seen, whatever the underlying cause. Endovascular closure of the fistula tract is a safe and efficient minimally invasive treatment modality with satisfactory durability. However, we should consider unpredictable complications, like coil or plug migration. Open surgery provides total and permanent correction of the pathological and anatomical changes, and has superior durability.

\section{Acknowledgements and disclosures}

The authors declare that there is no conflict of interest and no financial supporter.

The case report was presented recently as a poster presentation at the 18th Congress of the Turkish Society for Vascular and Endovascular Surgery.

None of the material in this manuscript has been published previously or is currently under consideration for publication elsewhere.

Informed consent has been obtained from the patient's guardian for publication of the case report and accompanying images.

\section{References}

1.Guneyli, S, Cinar, C, Bozkaya, H, Korkmaz, M, Oran, I, Endovascular management of congenital arteriovenous fistulae in the neck, Diagnostic and Interventional Imaging, 2016, 97(9), 8715

2. Wang, M, Fan, W, Mungur, R, Gu, J, Wan, S, Endovascular treatment of congenital internal carotid-juguler fistula, Frontiers in Neurology, 2018, 9, 1118

3. Puca, A, Pignatelli, F, An adult case of idiopathic internal carotidjuguler vein arteriovenous fistula, Annals of Vascular Surgery, 2015, 29(4), 842.e5-7.

4. Wadhwa, R, Toms, J, Nanda, A, Abreo, K, Cuellar, H, Angioplasty and stenting of a jugular-carotid fistula resulting from the inadvertent placement of a hemodialysis catheter: Case report and review of literature, Seminars of Dialysis, 2012, 25(4), 460-3.

5. DuBose, J, Recinos, G, Teixeira, P.G.R, Inaba, K, Demetriades, D, Endovascular stenting for the treatment of traumatic internal carotid injuries: Expanding experience. Journal of Trauma, 2008, 65, 156166.

6. Ramsay, D.W, McAuliffe, W, Traumatic pseudoaneurysm and high flow arteriovenous fistula involving internal jugular vein and common carotid artery, Treatment with covered stent and embolization. Australasian Radiology, 2003, 47(2), 177-80.

7. Babu, A, Garg, H, Sagar, S, Gupta, A, Kumar, S, Penetrating neck injury: Collaterals for another life after ligation of common carotid artery and subclavian artery, Chinese Journal of Traumatology, 2017, 20(1), 56-58

8. Girona, J, Marti, G, Betrian, P, Gran, F, Casaldaliga, J, Percutaneous embolisation of vascular fistulas using coils or 
amplatzer vascular plugs, Revista Espanola de Cardiologia, 2009, 62(7), 765-73.

9.Ramakrishnan, S, Vascular plugs-A key companion to interventionists- 'Just plug it', Indian Heart Journal, 2015, 67(4), $399-405$.

http://edergi.cbu.edu.tr/ojs/index.php/cbusbed isimli yazarın CBU-SBED başlıklı eseri bu Creative Commons Alınt1-Gayriticari4.0 Uluslararası Lisansı ile lisanslanmıştır.

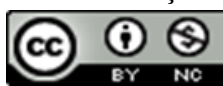

